\title{
ANALYSIS OF THE HARVESTING QUALITY OF REDCURRANT WITH A TRAILED COMBINE
}

\author{
Grażyna Szmajda ${ }^{\mathrm{a}^{*}}$, Tomasz Nowakowski ${ }^{\mathrm{b}}$ \\ a Faculty of Production Engineering, Warsaw University of Life Sciences, Poland, \\ e-mail: graszmaj@ onet.pl, ORCID 0000-0002-7247-8527 \\ b Institute of Mechanical Engineering, Warsaw University of Life Sciences, Poland, \\ e-mail: tomasz_nowakowski@sggw.pl, ORCID 0000-0003-2376-4284
}

*Corresponding author: e-mail: graszmaj@onet.pl

\begin{tabular}{|c|c|}
\hline ARTICLE INFO & ABSTRACT \\
\hline $\begin{array}{l}\text { Article history: } \\
\text { Received: December } 2019 \\
\text { Received in the revised form: } \\
\text { February } 2020 \\
\text { Accepted: March } 2020\end{array}$ & \multirow{2}{*}{$\begin{array}{l}\text { Field tests on the quality of shaking off redcurrant fruit Rosetta culti- } \\
\text { var with a half-row trailer harvester "Marek" produced by Dom-Wid } \\
\text { were carried out. The tests were performed at two average working } \\
\text { speeds } \bar{v}_{1}=0.47 \mathrm{~m} \cdot \mathrm{s}^{-1} ; \bar{v}_{2}=0.60 \mathrm{~m} \cdot \mathrm{s}^{-1} \text { and two rotational speeds of } \\
\text { a tractor } \mathrm{n}_{1}=1500 \mathrm{rpm} ; \mathrm{n}_{2}=1900 \mathrm{rpm} \text {. The length and diameter of } \\
\text { shoots of redcurrant, length of a bunch, number of fruits in a bunch } \\
\text { and mass of fruit were measured. Weather conditions were presented: } \\
\text { rain fall, air temperature and moisture. Analysis of results showed that } \\
\text { the working speed and the rotational speed has a significant impact on } \\
\text { the quality and amount of the yield. At the highest rotations, the } \\
\text { harvesting quality of fruit by a harvester was the worst and was } \\
77.15 \% \text {. }\end{array}$} \\
\hline $\begin{array}{l}\text { Key words: } \\
\text { redcurrant, } \\
\text { harvesting quality }\end{array}$ & \\
\hline
\end{tabular}

\section{Introduction}

A mechanised technology replaces manual harvesting which constitutes $80 \%$ of labour expenditure in berry production including redcurrant. In a several-hectare farm, planting of various redcurrant cultivars or species with a different degree of maturation is needed. Thanks to this, the harvesting may be extended in time and relevantly adjusted to the owned machines. When choosing a berry cultivar, one considers its resistance to diseases and pests, prolificity and a possibility of mechanical harvesting (Ochmian, 2013; Knjaziew, 2000). Bushes with stiff shoots and average and short bunches are the best adjusted for combine harvesting. More firm fruit are less susceptible to mechanical damage (Hansen, 2014, Rabcewicz, 2006). In a several-hectare big farm, it is profitable to use half-row combines. Majority of producers says that a combine harvests over $90 \%$ of the good-quality fruit due to relevant selection of work parameters. The speed of driving for redcurrant is $0.8-1.5 \mathrm{~km} \cdot \mathrm{h}^{-1}$ (Błaszczyńska, 2010; Nowakowski, 2005). The quality of harvesting of redcurrant is significantly influenced by the maturity of redcurrant, working speed, rotational speed of an engine, amplitude and frequency of vibrations, cultivar of redcurrant, size of bushes and manner of cultivation. The increase of the working speed causes simultaneously the increase in the number of damages to shoots. The quality is determined based on 
the number of fruits not collected by the combine or thrown behind the combine, the number of contaminations and degree of damage to shoots (Kowalczuk, 2008; Salamon, 1997). A drawback of these combines is a necessity of a repeated crossing through each row of the plantation as a result of which bushes are divided two times (Wilczyński, 2017; Węgrzyn, 2005). The aim of the paper was to determine the size of losses of redcurrant fruit Rosetta cultivar during harvesting with the use of a half-row combine. Losses of fruit left on shoots and fruit that dropped to the ground were presented.

\section{Materials and Methods}

The object of field studies was a half-row trailed combine "Marek" designed for berry fruit harvesting (chokeberry, red currant, raspberry, gooseberry). The source of the combine drive is a farm tractor with the minimum power of $22 \mathrm{~kW}(30 \mathrm{KM})$. Half-row combines harvest fruit from a half of a row during one working crossing. The working length of a combine is $5.86 \mathrm{~m}$, width $2.2 \mathrm{~m}$ and height $2.3 \mathrm{~m}$. The half-row combine comprises a frame supported on two driving wheels and is equipped with working units (Fig. 1). A cross and longitudinal conveyor, shaker with metal fingers and a fan. In the harvesting unit of the combine there is one shaker with nine shaking elements mounted to the mobile frame. A hydraulic system supplies working units. Efficiency of the combine harvesting is $0.1-0.2 \mathrm{ha} \cdot \mathrm{h}^{-1}$. The harvested fruit are cleaned of impurities and then the harvested fruit are placed in boxes.
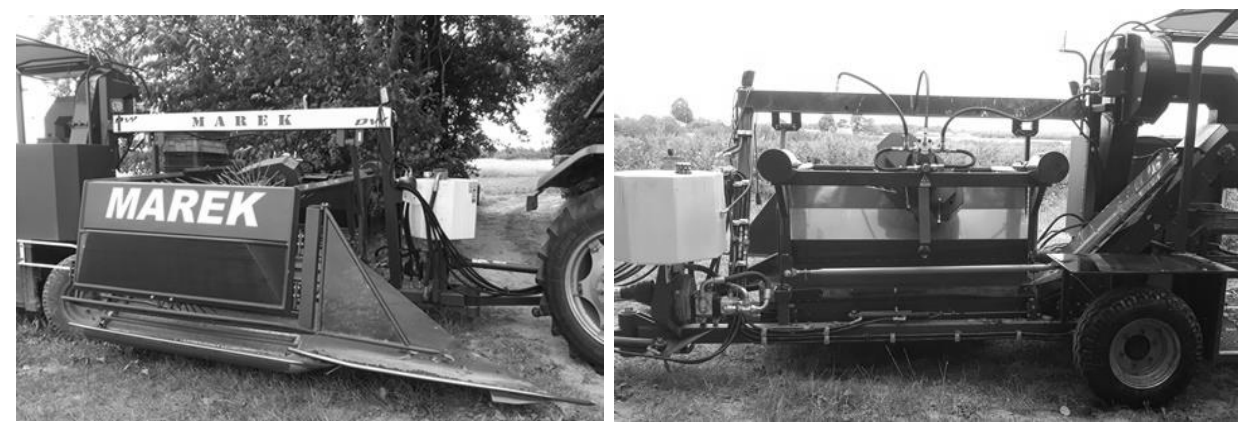

Figure 1. Half-Row harvester „MAREK” producer Dom - Wid

The field trials were carried out for redcurrant Rosetta cultivar in Wierzchowiska Drugie, Province of Lipsko in Mazowieckie Voivodeship (Fig. 2,3). Bushes of redcurrant are adjusted to harvesting with a combine and the harvested fruit are designed mainly for the processing industry. The plantation with the area of 1.69 ha grows on the IV $\mathrm{b}$ and $\mathrm{V}$ soil bonification class. Two cultivars of redcurrant Rondom and Rosetta are cultivated on the plot with the distribution of $5.40 \mathrm{~m}$ between the rows and $0.45 \mathrm{~m}$ in a row. The average width of the investigated bushes was $0.82 \mathrm{~m}$ while the height of $1.11 \mathrm{~m}$. Redcurrant Rosetta has bunches with the average length of $54.73 \mathrm{~mm}$, with the average mass of $4.17 \mathrm{~g}$. The number of fruits in one bunch was 3-18 pcs. Redcurrant fructifies on short shoots that grow from young shoots (Moyer et al., 2002, Pikuła, 2016). The investigated redcurrant produced from 8 to 106 pcs of this-year shoots and 3-22 pcs of skeleton shoots. 
Quarters of redcurrant are mechanically cultivated (bare fallow) with a cultivation unit and with herbicide fallow. Crop protection substances in the investigated plantation of redcurrant were used from the 4th quarter of March -2 nd quarter of July. Suitable cutting of bushes facilitates the combine operation during harvesting (Salamon, 2002). Bushes are cut before the vegetation starts (early spring) and after harvesting by thinning cutting.

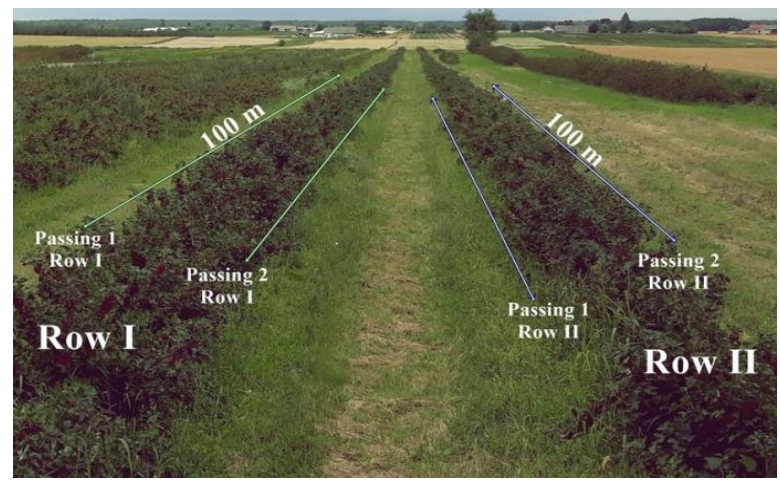

Figure 2. Rosetta redcurrant plantation

a)
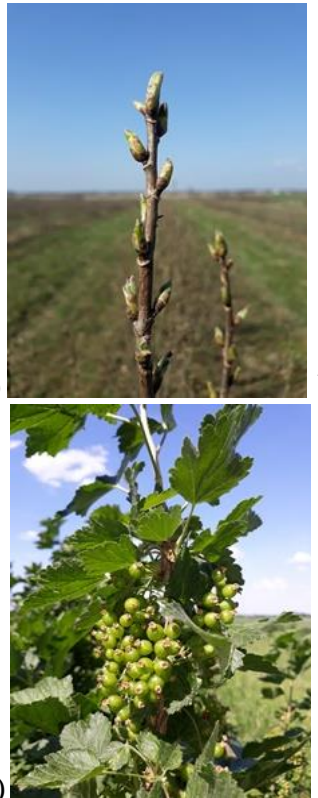

b)
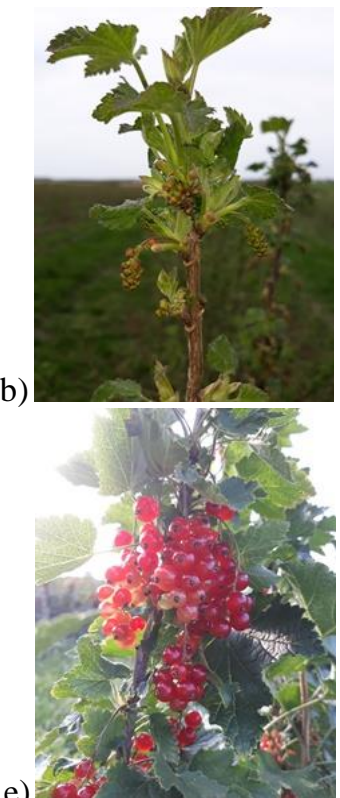
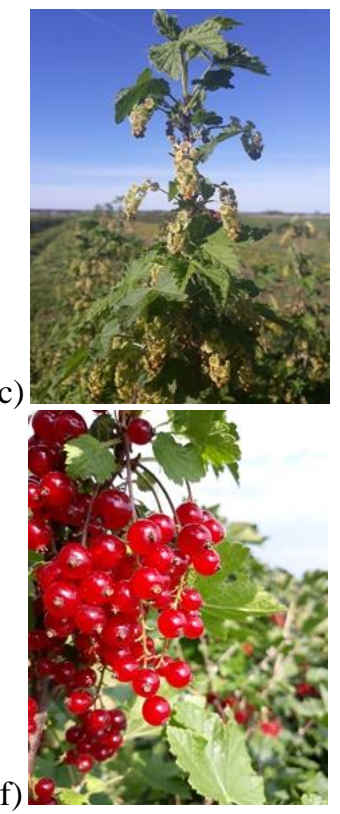

Figure 3. The stages of growth of Rosetta redcurrant in 2018:a) 8 April (beginning of vegetation, b) 15 April (ends fleaves except for bud scales), c) 22 April (beginning of flowering stage), d) 13 May (first fruit on bunches), e) 12 April (produced 50\% of fruit), f) 30 April (harvesting) 
Availability of water and suitable temperature are a factor that influences the size of redcurrant yield. Water scarcity and a high temperature reduce the number and quality of fruit (Lamont, 2012). The temperature was measured with an outside thermometer, it was placed in the shady place and the measurement range was $-50^{\circ} \mathrm{C}$ to $+50^{\circ} \mathrm{C}$. The rain fall was measured with a rain gauge. Precision of the measurement scale of the device was $0.5 \mathrm{~mm} \cdot \mathrm{m}^{-2}$ and a single time measurement of precipitation was $35 \mathrm{~mm} \cdot \mathrm{m}^{-2}$. The measurement of the rain fall was checked and recorded daily. Measurements of the conditions of field studies were carried out from the start of vegetation to the end of harvesting of redcurrant 04 April2018 - 17July 2018 (table 1).

Table 1.

Characteristics of weather conditions in the vegetation period to harvesting

\begin{tabular}{lcccc}
\hline Parameter & Date & $\begin{array}{c}\text { Amount of precipitation } \\
{[\mathrm{mm}]}\end{array}$ & $\begin{array}{c}\text { Temperature } \\
{\left[{ }^{\circ} \mathrm{C}\right]}\end{array}$ & $\begin{array}{c}\text { Moisture } \\
{[\%]}\end{array}$ \\
\hline \multirow{3}{*}{ MAX } & $4.4 .2018-30.5 .2018$ & 8.5 & 28 & 70 \\
& $1.5 .2018-30.5 .2018$ & 25 & 30 & 90 \\
& $1.4 .2018-30.4 .2018$ & 12.5 & 31 & 80 \\
& $1.7 .2018-17.7 .2018$ & 17.5 & 30 & 95 \\
\hline \multirow{3}{*}{ MIN } & $4.4 .2018-30.4 .2018$ & 12 & 12 & 35 \\
& $1.5 .2018-30.5 .2018$ & 15 & 15 & 25 \\
& $1.6 .2018-30.6 .2018$ & 16 & 16 & 30 \\
\multirow{4}{*}{ Standard } & $1.7 .2018-17.7 .2018$ & 15 & 15 & 30 \\
\hline \multirow{4}{*}{ deviation } & $4.4 .2018-30.4 .2018$ & 2.92 & 3.90 & 8.05 \\
& $1.5 .2018-30.5 .2018$ & 9.42 & 4.45 & 18.04 \\
& $1.6 .2018-30.6 .2018$ & 3.43 & 4.48 & 13.61 \\
\multirow{3}{*}{ Total } & $1.7 .2018-17.7 .2018$ & 7.77 & 4.26 & 18.12 \\
\hline & $4.4 .2018-30.4 .2018$ & 22.5 & - & - \\
& $1.5 .2018-30.5 .2018$ & 43 & - & - \\
\hline
\end{tabular}

The size of bushes influences the quality of harvesting and appropriate setting of combine shakers and adjustment of the speed to fruit harvesting (Wawrzyńczak, 2003). Measurements of the plantation taken included: shoots length, diameter of shoots, number of shoots, width, and height of a bush. A diameter of shoots was measured in the half-length and at the base of a bush. An analogue calliper was used for determination of the diameter of redcurrant shoots. The measurement range of a device is $0-500$ with a precision up to $0.05 \mathrm{~mm}$. A measurement tape STANLEY with $3 \mathrm{~m}$ length and precision of $1 \mathrm{~mm}$ was used for measurement of the length of shoots, width and height of a bush, distance of shoots and planting of bushes. The distance of shoots in a row was measured at the height of $0.20 \mathrm{~m}$ 
Analysis of the harvesting...

over the redcurrant fallow. The length of annual and skeleton shoots was measured. The width of a bush was measured perpendicularly to the row.

The measurement of the fruit mass that fell on the ground before $\left(m_{r}\right)$ and after harvesting with a combine $\left(m_{o}\right)$, that remained on shoots $\left(m_{p}\right)$ were carried out with a weighting machine with a precision of $0.1 \mathrm{~g}$. With one working crossing the combine harvested fruit from more than one half of the row of $100 \mathrm{~m}$ long distance. Then, six measurement trials of fruit loss were made on the distance. The measurement of the mass of the combine harvesting of redcurrant $\left(m_{z}\right)$ was made with a platform scales with a measurement system. The maximum load capacity of the scales is $1500 \mathrm{~kg}$ with a weighting precision of $300 \mathrm{~g}$.

The total mass harvested by a combine from one whole row was determined acc. to the formula:

$$
m_{g}=m_{z 1}+m_{z 2}
$$

where:

$m_{z 1} \quad-$ mass of fruit harvested with a combine from a half of the row from the first crossing in the row, $[\mathrm{kg}]$

$m_{z 2} \quad-$ mass of fruit harvested with a combine from a half of the row from the second crossing in the row, $[\mathrm{kg}]$

$m_{g} \quad-$ mass of fruit harvested with a combine from the entire row, $[\mathrm{kg}]$

The total losses of redcurrant fruit were determined from the following formula:

$$
S_{c}=\sum_{i=1}^{n} m_{p}+\left(\sum_{i=1}^{n} m_{o}-\sum_{i=1}^{n} m_{r}\right)
$$

where:

$S_{c} \quad-$ total loss, $[\mathrm{kg}]$

$m_{p} \quad-$ mass of fruit from i-th measurement of the fruit that remained on shoots, [kg]

$m_{o} \quad-$ mass of fruit from i-th measurement of the fruit that remained on ground, $[\mathrm{kg}]$

$m_{r} \quad-$ mass of fruit from i-th measurement on the ground before harvesting, [kg]

Fruit losses that fell to the ground and their percentage participation was determined according to the formula:

$$
\begin{gathered}
S_{z}=\sum_{i=1}^{n} m_{o}-\sum_{i=1}^{n} m_{r} \\
S_{z \%}=\frac{S_{z}}{m_{c}} * 100 \%
\end{gathered}
$$

where:

$S_{Z} \quad-\quad$ fruit loss that fell to the ground, $[\mathrm{kg}]$

$m_{c} \quad-$ total mass of fruit, $[\mathrm{kg}]$

Fruit losses that remained on shoots and their percentage participation was determined according to the formula:

$$
S_{p}=\sum_{i=1}^{n} m_{p}
$$




$$
S_{p \%}=\frac{S_{p}}{m_{c}} * 100 \%
$$

where:

$S_{p} \quad-$ left on shoots, $[\mathrm{kg}]$

$m_{p} \quad$ - mass of fruit from i-th remained on shoots, [kg]

\section{Results and Discussion}

The average values of a plantation were obtained from 50 measurement trials. The results of measurements of properties of fruit and bunches of the investigated redcurrant was obtained selected randomly from 100 trials (table 2 ).

Table 2.

Characteristics of Rosetta redcurrant plantation

\begin{tabular}{|c|c|c|c|c|c|c|c|}
\hline Specification & Min & Max & Average & $\begin{array}{l}\text { Standard } \\
\text { deviation }\end{array}$ & $\begin{array}{c}\text { Standard } \\
\text { error }\end{array}$ & Distribution & $\begin{array}{l}\text { Coefficient } \\
\text { of variation }\end{array}$ \\
\hline Distribution of rows [m] & 4.4 & 4.4 & 4.4 & 0 & 0 & 0 & 0 \\
\hline $\begin{array}{l}\text { Distance between bushes } \\
\text { in a row }[\mathrm{m}]\end{array}$ & 0.45 & 0.45 & 0.45 & 0 & 0 & 0 & 0 \\
\hline Length of shoots & 0.2 & 1.4 & 0.85 & 0.34 & 0.03 & 1.2 & 0.4 \\
\hline $\begin{array}{l}\text { Number of } \\
\text { skeleton shoots } \\
\text { in a bush [pcs] }\end{array}$ & 3 & 22 & 9.4 & 3.87 & 0.39 & 19 & 0.41 \\
\hline $\begin{array}{l}\text { Number of this year's } \\
\text { shoots } \\
\text { in a bush [pcs] }\end{array}$ & 8 & 106 & 51.72 & 21.77 & 2.18 & 98 & 0.42 \\
\hline Height of bushes [m] & 0.65 & 1.5 & 1.11 & 0.18 & 0.02 & 0.85 & 0.16 \\
\hline Width of bushes [m] & 0.2 & 1.5 & 0.82 & 0.33 & 0.03 & 1.3 & 0.4 \\
\hline $\begin{array}{l}\text { Diameter of shoots at the } \\
\text { base [mm] }\end{array}$ & 8 & 18 & 12.42 & 2.71 & 0.27 & 10 & 0.22 \\
\hline $\begin{array}{l}\text { Diameter of shoots inside } \\
\text { a shoot [mm] }\end{array}$ & 5 & 13 & 8.14 & 1.64 & 0.16 & 8 & 0.2 \\
\hline $\begin{array}{l}\text { Distance between shoots } \\
(20 \mathrm{~cm})[\mathrm{cm}]\end{array}$ & 3. & 29 & 15.41 & 6.23 & 0.62 & 26 & 0.4 \\
\hline
\end{tabular}


Analysis of the harvesting...

Table 3.

Characteristics of fruit for Rosetta redcurrant

\begin{tabular}{lccccccc}
\hline Specification & Min & Max & Average & $\begin{array}{c}\text { Standard } \\
\text { deviation }\end{array}$ & $\begin{array}{c}\text { Standard } \\
\text { error }\end{array}$ & Distribution & $\begin{array}{c}\text { Coefficient } \\
\text { of variation }\end{array}$ \\
\hline $\begin{array}{l}\text { Length of bunches } \\
\text { [mm] }\end{array}$ & 37 & 79 & 54.73 & 9.07 & 0.91 & 42 & 0.17 \\
\hline $\begin{array}{l}\text { Number of fruits in a } \\
\text { bunch [pcs] }\end{array}$ & 3 & 18 & 10.24 & 2.89 & 0.29 & 15 & 0.28 \\
\hline $\begin{array}{l}\text { Mass of 10 pcs of } \\
\text { fruit [g] }\end{array}$ & 2 & 6 & 4.17 & 0.87 & 0.09 & 4 & 0.21 \\
\hline
\end{tabular}

The most efficiently shaken was redcurrant with the tractor speed of $0.47 \mathrm{~m} \cdot \mathrm{s}^{-1}$ (table 4 , figure 4). Mass harvested from the entire row was two time bigger at the speed of $1500 \mathrm{rpm}$ than the speed of $1900 \mathrm{rpm}$ (table 5).

Table 4.

Characteristics of harvesting of Rosetta redcurrant with a combine

\begin{tabular}{|c|c|c|c|c|c|c|c|c|}
\hline $\begin{array}{l}3 \\
0 \\
2\end{array}$ & 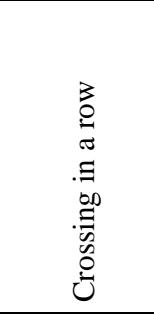 & 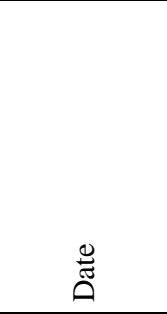 & 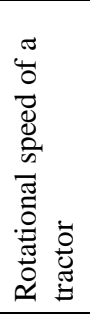 & 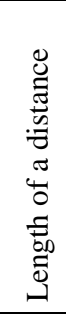 & 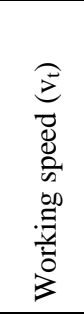 & 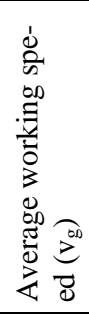 & 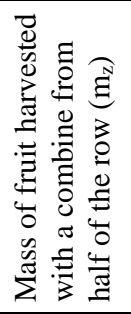 & 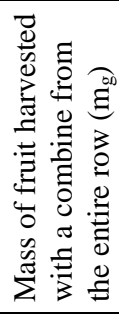 \\
\hline- & - & - & $\mathrm{rpm}$ & {$[\mathrm{m}]$} & $\mathrm{m} \cdot \mathrm{s}^{-1}$ & $\mathrm{~m} \cdot \mathrm{s}^{-1}$ & {$[\mathrm{~kg}]$} & {$[\mathrm{kg}]$} \\
\hline 1 row & 1 crossing & 03.07.2018 & 1500 & 100 & 0.45 & \multirow{2}{*}{0.47} & 129 & \multirow{2}{*}{209} \\
\hline 1 row & 2 crossings & 03.07 .2018 & 1500 & 100 & 0.48 & & 80 & \\
\hline 2 rows & 1 crossing & 03.07.2018 & 1900 & 100 & 0.56 & \multirow{2}{*}{0.} & 74 & \multirow{2}{*}{108} \\
\hline 2 rows & 2 crossings & 03.07 .2018 & 1900 & 100 & 0,64 & & 34 & \\
\hline
\end{tabular}


Grażyna Szmajda, Tomasz Nowakowski

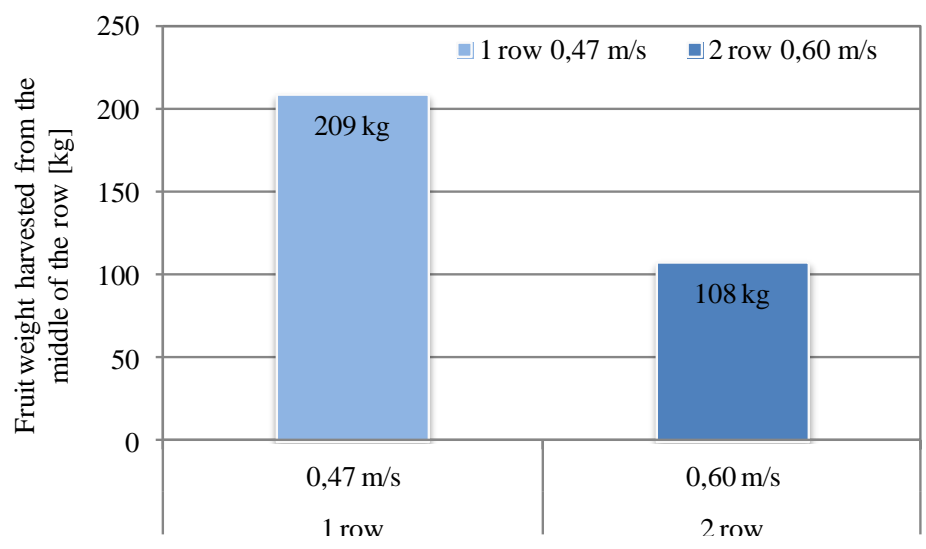

Figure 4. Mass of fruit harvested with a combine from a row depending on the working speed of a unit

Table 5.

Results of research on quantitative losses of redcurrant fruit harvested with a combine

\begin{tabular}{|c|c|c|c|c|c|c|c|c|}
\hline$\dot{z}$ & $\begin{array}{l}3 \\
0 \\
\alpha\end{array}$ & 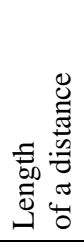 & 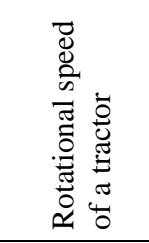 & 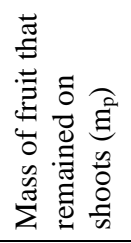 & 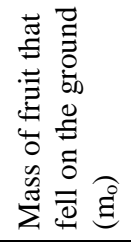 & 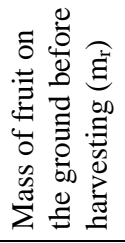 & $\begin{array}{l}\widehat{\sigma} \\
0 \\
0 \\
0 \\
0 \\
.\end{array}$ & 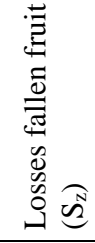 \\
\hline- & - & {$[\mathrm{m}]$} & {$\left[\operatorname{rot} \cdot \mathrm{min}^{-1}\right]$} & {$[\mathrm{kg}]$} & {$[\mathrm{kg}]$} & {$[\mathrm{kg}]$} & {$[\mathrm{kg}]$} & {$[\mathrm{kg}]$} \\
\hline 1 & 1 & 20 & 1500 & 2.739 & 2.24 & 0.316 & 4.663 & 1.924 \\
\hline 2 & 1 & 20 & 1500 & 1.043 & 5.241 & 0.254 & 6.03 & 4.987 \\
\hline 3 & 1 & 20 & 1500 & 1.741 & 4.749 & 0.252 & 6.238 & 4.497 \\
\hline 4 & 1 & 20 & 1500 & 1.374 & 3.501 & 0.366 & 4.509 & 3.135 \\
\hline 5 & 1 & 20 & 1500 & 2.088 & 3.844 & 0.116 & 5.816 & 3.728 \\
\hline 6 & 1 & 20 & 1500 & 2.04 & 3.326 & 0.058 & 5.308 & 3.268 \\
\hline \multicolumn{9}{|c|}{ ROSETTA } \\
\hline 1 & 2 & 20 & 1900 & 0.24 & 5.062 & 0.242 & 5.06 & 4.82 \\
\hline 2 & 2 & 20 & 1900 & 0.968 & 4.025 & 0.316 & 4.677 & 3.709 \\
\hline 3 & 2 & 20 & 1900 & 1.002 & 6.488 & 0.238 & 7.252 & 6.25 \\
\hline 4 & 2 & 20 & 1900 & 0.452 & 5.6 & 0.082 & 5.97 & 5.518 \\
\hline 5 & 2 & 20 & 1900 & 1.099 & 2.81 & 0.196 & 3.713 & 2.614 \\
\hline 6 & 2 & 20 & 1900 & 0.541 & 5.087 & 0.318 & 5.31 & 4.769 \\
\hline
\end{tabular}




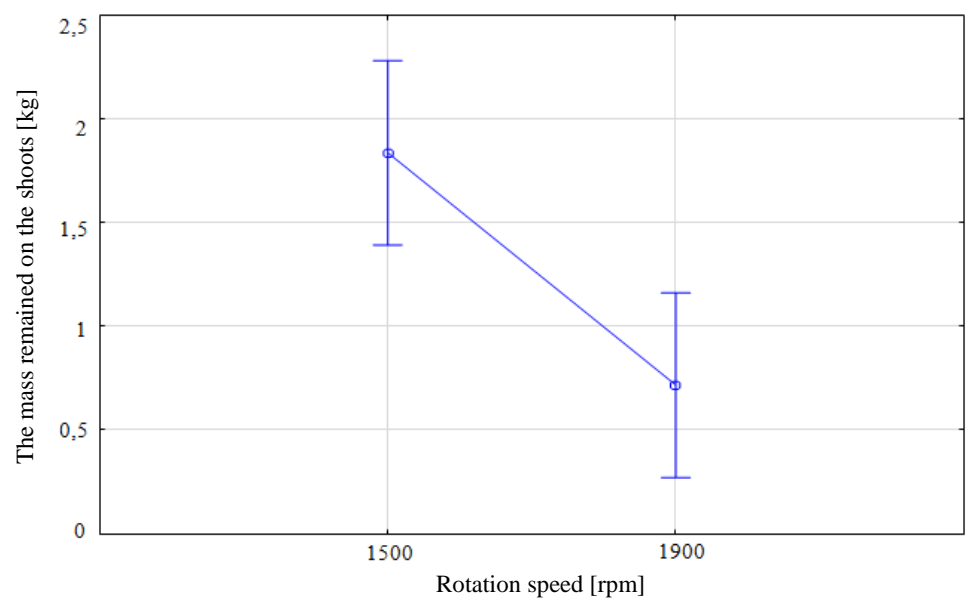

Figure 5. Change in the value of fruit remaining on shoots $\left(m_{p}\right)$ depending on the rotational speed of the shaker drive motor ( $n$ ) for ROSETTA red currant

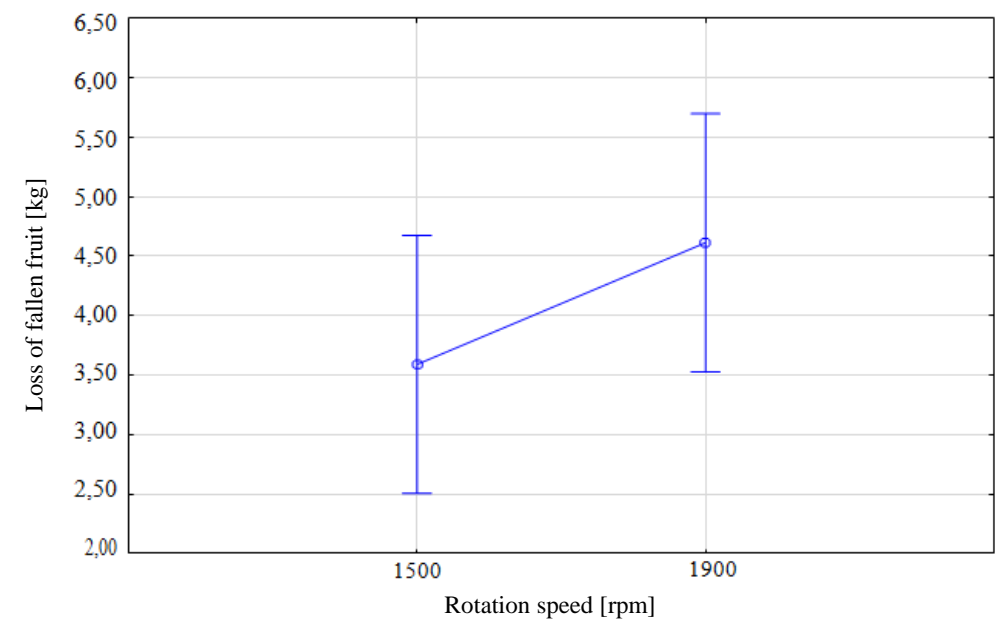

Figure 6. Change in the value of currant fruit that fall to the ground $\left(S_{z}\right)$ depending on the rotational speed of the shaker drive engine (n) for ROSETTA red currant

Number of losses of fruit remaining on shoots and fallen to the ground depends on the rotational speed of a combine. The highest loss of mass was $32.564 \mathrm{~kg}$ for the speed of $1500 \mathrm{rpm}$ (table 4,5). Thus, more fruit remained on shoots at the speed of $1900 \mathrm{rpm}$ (figure 4). To avoid such losses manual harvesting after combine crossing may be introduced. At a higher rotational speed, losses that fell to the ground are higher. 
Grażyna Szmajda, Tomasz Nowakowski

Table 6

Loss of fruit after combine harvesting

\begin{tabular}{|c|c|c|c|c|c|c|c|}
\hline \multicolumn{8}{|c|}{ Losses at harvesting of blackcurrant and redcurrant } \\
\hline No. & $\begin{array}{l}\text { Redcurrant } \\
\text { species }\end{array}$ & $\begin{array}{l}\text { Redcurrant } \\
\text { cultivar }\end{array}$ & $\begin{array}{l}\text { Rotational } \\
\text { speed } \\
\text { of a tractor }\end{array}$ & MIN & MAX & $\begin{array}{l}\text { Arithmetical } \\
\text { mean }\end{array}$ & $\begin{array}{l}\text { Standard } \\
\text { deviation }\end{array}$ \\
\hline- & - & - & {$\left[\mathrm{rot} \cdot \mathrm{min}^{-1}\right]$} & {$[\mathrm{kg}]$} & {$[\mathrm{kg}]$} & {$[\mathrm{kg}]$} & {$[\mathrm{kg}]$} \\
\hline \multicolumn{8}{|c|}{ Losses $(\mathrm{S})$} \\
\hline 1 & Red & Rosetta & 1500 & 4.509 & 6.238 & 5.427 & 0.723 \\
\hline 2 & Red & Rosetta & 1900 & 3.713 & 7.252 & 5.33 & 1.202 \\
\hline \multicolumn{8}{|c|}{ Losses in the form of fallen fruit $(\mathrm{Sz})$} \\
\hline 4 & Red & Rosetta & 1500 & 1.924 & 4.987 & 3.59 & 1.084 \\
\hline 5 & Red & Rosetta & 1900 & 2.614 & 6.25 & 4.613 & 1.295 \\
\hline \multicolumn{8}{|c|}{ Losses in the form of fruit that remained on shoots $\left(\mathrm{m}_{\mathrm{p}}\right)$} \\
\hline 6 & Red & Rosetta & 1500 & 1.043 & 2.739 & 1.8375 & 0.595 \\
\hline 7 & Red & Rosetta & 1900 & 0.240 & 6.488 & 0.717 & 0.352 \\
\hline
\end{tabular}

Table 7.

Mass of harvested fruit of redcurrant

\begin{tabular}{lccc}
\hline Specification & $\begin{array}{c}\text { Unit of } \\
\text { measurement }\end{array}$ & $\begin{array}{c}\text { Rosetta redcurrant } \\
1900[\mathrm{rpm}]\end{array}$ & $\begin{array}{c}\text { Rosetta redcurrant } \\
1500[\mathrm{rpm}]\end{array}$ \\
\hline Total mass of fruit & {$[\mathrm{kg}]$} & 139.982 & 241.564 \\
Mass harvested by a combine & {$[\mathrm{kg}]$} & 108 & 209 \\
Total loss & {$[\mathrm{kg}]$} & 31.982 & 32.564 \\
Losses that remained on shoots & {$[\mathrm{kg}]$} & 4.302 & 11.025 \\
Losses that fell to the ground & {$[\mathrm{kg}]$} & 27.68 & 21.539 \\
\hline & Percentage participation of fruit & 100 \\
\hline The total amount of harvested & {$[\%]$} & 100 & 86.52 \\
fruit & {$[\%]$} & 77.15 & 13.48 \\
Amount harvested by a combine & {$[\%]$} & 22.85 & 4.56 \\
Total loss & {$[\%]$} & 3.07 & 8.92 \\
Losses that remained on shoots & {$[\%]$} & 19.77 & \\
Losses that fell to the ground & & & \\
\hline
\end{tabular}




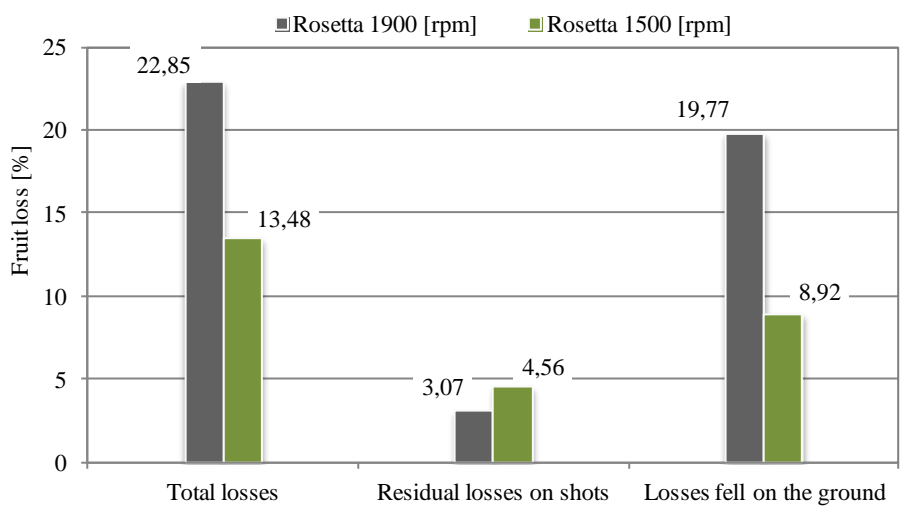

Figure 7. Percentage share of redcurrant fruit losses

\section{Conclusion}

In the mechanical combine harvesting, the size of the rotational speed of the shaker drive engine, working speed influence the precision of harvesting (Salamon, 2007). The optimal working speed at the redcurrant harvesting with a combine is $0.45 \mathrm{~m} \cdot \mathrm{s}^{-1}$ for redcurrant. The highest percentage of shaken fruit was obtained at the rotational speed of a tractor shaker drive that was $1500 \mathrm{rpm}$, and the precision of harvesting was $85.11 \%$. The lowest value of the harvesting precision was $77.15 \%$, it was obtained at the highest revolutions of the tractor shaker drive $1900 \mathrm{rot} / \mathrm{min}$ and the working speed within the range of $0.56 \mathrm{~m} / \mathrm{s}-$ $0.64 \mathrm{~m} \cdot \mathrm{s}^{-1}$. The increase of the rotational speed of a tractor shaker drive to $1900 \mathrm{rot} / \mathrm{min}$ during harvesting caused that the sum of fruit losses was lower than the rotational speed of $1500 \mathrm{rot} \cdot \mathrm{min}^{-1}$ and amounted to $77.15 \%$.

\section{References}

Błaszczyńska, B. (2010). Uprawa porzeczek. Hortpress, Warszawa. ISBN: 9788361574569.

Chlebowska, D., Salamon, Z. (2001). Mechaniczny zbiór porzeczek. Hasło ogrodnicze 7, 9-10.

Gwozdecki, J. (2007). Porzeczki i agrest. Wydawnictwo Działkowiec, Warszawa, ISBN 83-8961524-4.

Hansen, S., Maughan, T., Balck, B. (2014). Red Currant in the Garden. Horticulture Science, 5, 3-4.

Knjaziew, S., Gurin, A. (2000). Wlijanije sadzaszczitnych połos na urożajnost czernoj smorodiny. Sadowodstwo $i$ Winogradarstwo 3, 10-11.

Kowalczuk, J., Zarajczyk, J., Leszcyński, N. (2008). Evaluation of the raspberries harvest quality of the WEREMCZUK's firm „NATALIA” combine. Agricultural engineering 2, 89-93.

Moyer, R., Hummer, K., Finn, Ch., Frel, B., Wrolstad, R. (2002). Anthocyanins, Phenolics and Antioxisant Capacity in Diverse Small Fruits: Vaccinium, Rubus, and Ribes. Journal of Agricultural and Food Chemistry, 4, 519-525.

Nowakowski, T. (2005). Przyczepiany kombajn do zbioru owoców jagodowych. Technika Rolnicza Ogrodnicza Leśna 4, 8-10.

Ochmmian, I. (2013). Comparison of fruit quality of three blackcurrant cultivars (RIBES NIGRUM L.) depending on their size. Folia Pomeranae Universitatis Technologiae Stentinsis, 97-106. 
Pikuła, W. (2016). Krzewy owocowe - Ślaski Ogród Botaniczny w Radzionkowie. Mikołów, Śląski Ogród Botaniczny. ISBN 978-83-939083-6-3.

Rabcewicz, J. (2006). Aechanizacja zbioru owoców jagodowych. Hasło ogrodnicze 7, 5-6.

Salamon, Z. (2007). Kombajn do zbioru owoców jagodowych. Opis patentowy PL 193726 B1.

Salamon, Z 2002). Wpływ wybranych parametrów kombajnu na zbiór owoców i na powstawanie uszkodzeń krzewów kilku gatunków roślin jagodowych. Zeszty Naukowe Instytutu Sadowadownictwa i Kwiaciarstwa Skierniewice, 331, 203-216.

Salamon, Z., Wawrzyńczak, P., Rabcewicz, J. (1997). Machine harvesting of berry bush fruits. Agricultural Engineering Problems, 61-68.

Wawrzyńczak, P. (2003). Zmechanizowanie technologii produkcji porzeczek i agrestu. Instytut Sadownictwa i Kwiaciarstwa (INSAD), 72-81.

Węgrzyn, A. (2005). Investigation problems concerning the losses of fruits and vegetables caused by harvesting machines. Problems of Agricultural Engineering 1, 49-56.

Wilczyński, K., Olesińska, K., Kałwa, K., Kobus, Z. (2017). Analysis of cultivation and composition, nutritional and health-promoting properties of black chokeberry fruit. Acta Scientiarum Polonorum Technica Agraria 16(1-2), 3-11.

Lamont, W., Harper, J. (2012) Irrigation for Fruit and Vegetable Production. Agricultural Alternatives, 2-3.

\section{ANALIZA JAKOŚCI ZBIORU PORZECZKI CZERWONEJ KOMBAJNEM PRZYCZEPIANYM}

Streszczenie. Przeprowadzono badania polowe nad jakością otrząsania owoców porzeczki czerwonej odmiany Rosetta kombajnem półrzędowym przyczepianym „Marek”, produkowanym w firmie Dom - Wid. Badania wykonano przy dwóch średnich prędkościach roboczych $\bar{v}_{1}=0,47 \mathrm{~m} / \mathrm{s} ; \bar{v}_{2}=0,60 \mathrm{~m} / \mathrm{s}$ oraz dwóch prędkościach obrotowych ciągnika $\mathrm{n}_{1}=1500 \mathrm{obr} . \mathrm{min} ; \mathrm{n}_{2}=1900 \mathrm{obr} . / \mathrm{min}$. Wykonano badania pomiaru długości i średnicy pędów porzeczki czerwonej, długości gron, liczby owoców w gronie oraz masy owoców. Przedstawiono warunki pogodowe: opad deszczu, temperatura i wilgotność powietrza. Analiza wyników wykazała, że prędkość robocza oraz prędkość obrotowa ma znaczący wpływ na jakość i ilość uzyskanego plonu. Przy najwyższych obrotach jakość zbioru owoców przez kombajn była najgorsza.

Słowa kluczowe: porzeczka czerwona, jakość zbioru 